\title{
HISTOFISIOLOGI KULIT
}

\author{
Sonny J. R. Kalangi
}

Bagaian Anatomi-Histologi Fakultas Kedokteran Universitas Sam Ratulangi Manado

E-mail: sonnykalangi@yahoo.com

"Tidak ada mantel ajaib yang dapat dibandingkan dengan kulit dalam berbagai perannya berupa kedap air, penghangat, tabir surya, pelindung, pendingin, sensitif terhadap rasa raba, suhu, dan nyeri, tahan dipakai dan dapat memperbaiki diri sendiri.”

Prof. R.D. Lockhart

Ahli anatomi terkenal berkebangsaan Skotlandia

(Author of Anatomy of the Human Body)

Kulit beserta turunannya, meliputi rambut, kuku, kelenjar sebasea, kelenjar keringat, dan kelenjar mamma disebut juga integumen. Fungsi spesifik kulit terutama tergantung sifat epidermis. Epitel pada epidermis ini merupakan pembungkus utuh seluruh permukaan tubuh dan ada kekhususan setempat bagi terbentuknya turunan kulit, yaitu rambut, kuku, dan kelenjar-kelenjar.

\section{KULIT SEBAGAI ORGAN}

Kulit merupakan organ yang tersusun dari 4 jaringan dasar:

1. Kulit mempunyai berbagai jenis epitel, terutama epitel berlapis gepeng dengan lapisan tanduk. Penbuluh darah pada dermisnya dilapisi oleh endotel. Kelenjar-kelenjar kulit merupakan kelenjar epitelial.

2. Terdapat beberapa jenis jaringan ikat, seperti serat-serat kolagen dan elastin, dan sel-sel lemak pada dermis.

3. Jaringan otot dapat ditemukan pada dermis. Contoh, jaringan otot polos, yaitu otot penegak rambut ( $m$. arrector pili) dan pada dinding pembuluh darah, sedangkan jaringan otot bercorak terdapat pada otot-otot ekspresi wajah.

4. Jaringan saraf sebagai reseptor sensoris yang dapat ditemukan pada kulit berupa ujung saraf bebas dan berbagai badan akhir saraf. Contoh, badan Meissner dan badan Pacini.

\section{Struktur kulit}

Kulit terdiri atas 2 lapisan utama yaitu epidermis dan dermis. Epidermis merupakan jaringan epitel yang berasal dari ektoderm, sedangkan dermis berupa jaringan ikat agak padat yang berasal dari mesoderm. Di bawah dermis terdapat selapis jaringan ikat longgar yaitu hipodermis, yang pada beberapa tempat terutama terdiri dari jaringan lemak.

\section{Epidermis}

Epidermis merupakan lapisan paling luar kulit dan terdiri atas epitel berlapis gepeng dengan lapisan tanduk. Epidermis hanya terdiri dari jaringan epitel, tidak mempunyai pembuluh darah maupun limf; oleh karenaitu semua nutrien dan oksigen diperoleh dari kapiler pada lapisan dermis.

Epitel berlapis gepeng pada epidermis ini tersusun oleh banyak lapis sel yang disebut keratinosit. Sel-sel ini secara tetap diperbarui melalui mitosis sel-sel dalam 


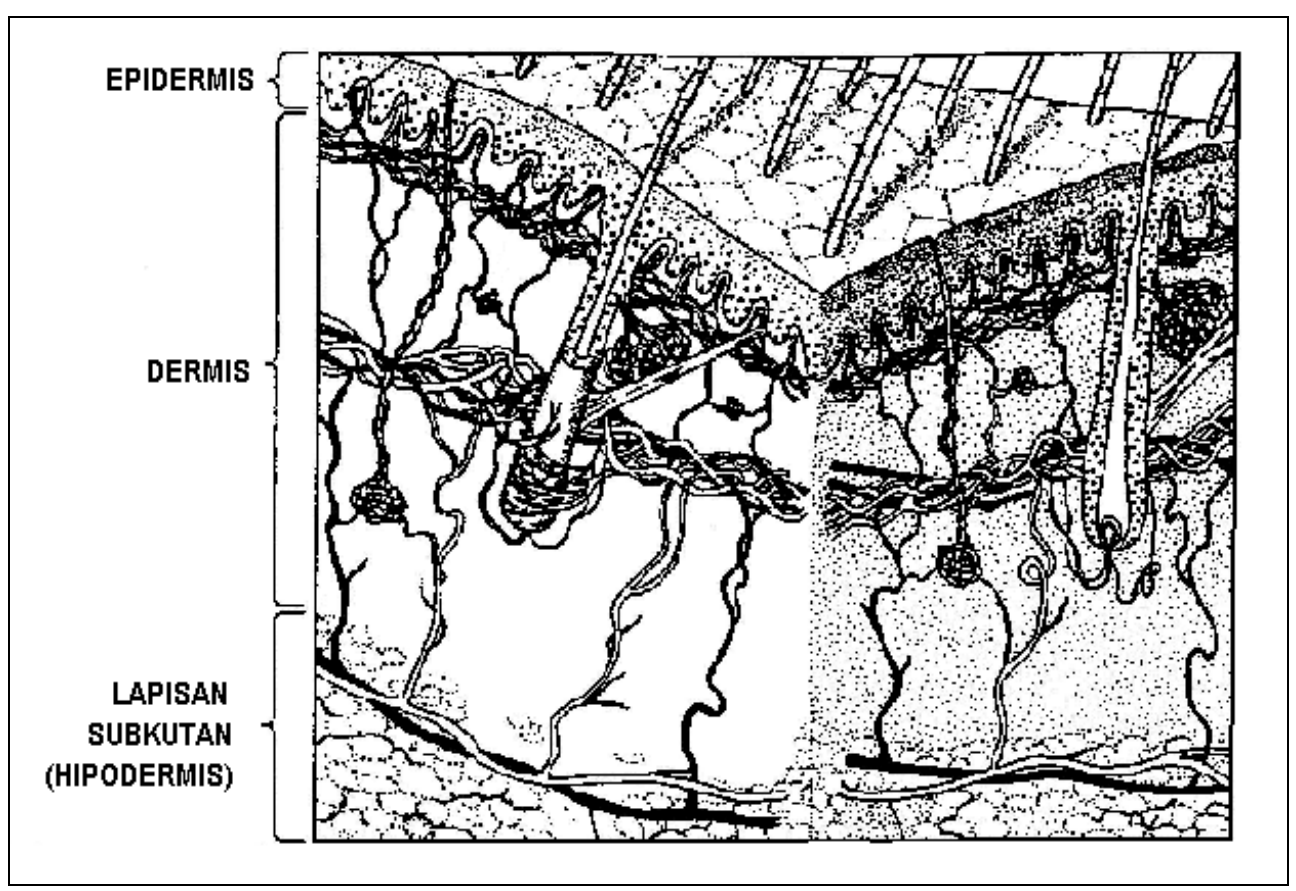

Gambar 1. Struktur kulit. Sumber: Kessel RG, 1998.

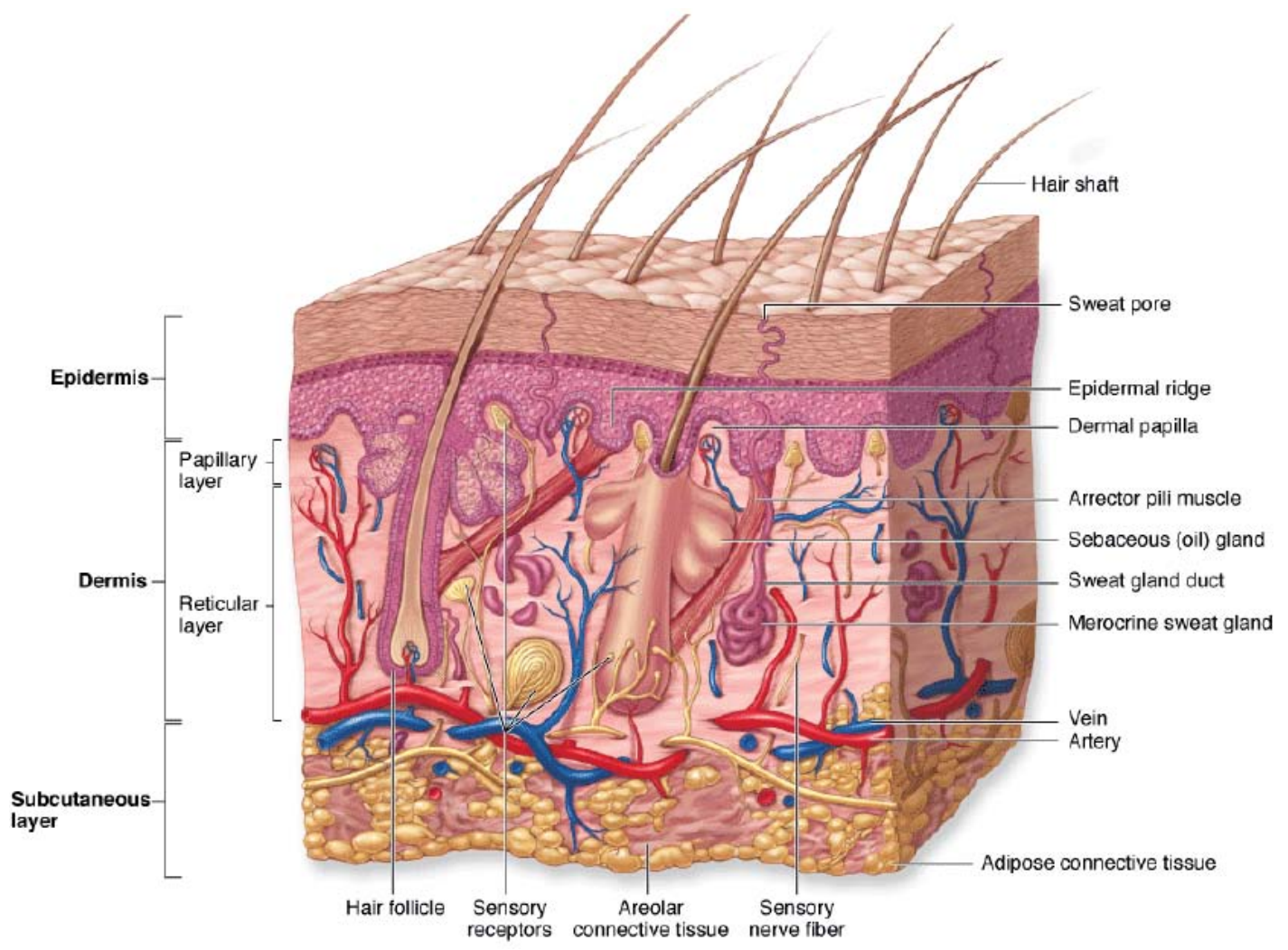

Gambar 2. Lapisan-lapisan dan apendiks kulit. Diagram lapisan kulit memperlihatkan saling hubung dan lokasi apendiks dermal (folikel rambut, kelenjar keringat, dan kelenjar sebasea). Sumber: Mescher AL, 2010. 
lapis basal yang secara berangsur digeser ke permukaan epitel. Selama perjalanannya, sel-sel ini berdiferensiasi, membesar, dan mengumpulkan filamen keratin dalam sitoplasmanya. Mendekati permukaan, selsel ini mati dan secara tetap dilepaskan (terkelupas). Waktu yang dibutuhkan untuk mencapai permukaan adalah 20 sampai 30 hari. Modifikasi struktur selama perjalanan ini disebut sitomorfosis dari sel-sel epidermis. Bentuknya yang berubah pada tingkat berbeda dalam epitel memungkinkan pembagian dalam potongan histologik tegak lurus terhadap permukaan kulit.

Epidermis terdiri atas 5 lapisan yaitu, dari dalam ke luar, stratum basal, stratum spinosum, stratum granulosum, stratum lusidum, dan stratum korneum.

\section{Stratum basal (lapis basal, lapis benih)}

Lapisan ini terletak paling dalam dan terdiri atas satu lapis sel yang tersusun berderet-deret di atas membran basal dan melekat pada dermis di bawahnya. Selselnya kuboid atau silindris. Intinya besar, jika dibanding ukuran selnya, dan sitoplasmanya basofilik. Pada lapisan ini biasanya terlihat gambaran mitotik sel, proliferasi selnya berfungsi untuk regenerasi epitel. Sel-sel pada lapisan ini bermigrasi ke arah permukaan untuk memasok sel-sel pada lapisan yang lebih superfisial. Pergerakan ini dipercepat oleh adalah luka, dan regenerasinya dalam keadaan normal cepat.

\section{Stratum spinosum (lapis taju)}

Lapisan ini terdiri atas beberapa lapis sel yang besar-besar berbentuk poligonal dengan inti lonjong. Sitoplasmanya kebiruan. Bila dilakukan pengamatan dengan pembesaran obyektif 45x, maka pada dinding sel yang berbatasan dengan sel di sebelahnya akan terlihat taju-taju yang seolah-olah menghubungkan sel yang satu dengan yang lainnya. Pada taju inilah terletak desmosom yang melekatkan sel-sel satu sama lain pada lapisan ini. Semakin ke atas bentuk sel semakin gepeng.

\section{Stratum granulosum (lapis berbutir)}

Lapisan ini terdiri atas 2-4 lapis sel gepeng yang mengandung banyak granula basofilik yang disebut granula keratohialin, yang dengan mikroskop elektron ternyata merupakan partikel amorf tanpa membran tetapi dikelilingi ribosom. Mikrofilamen melekat pada permukaan granula.

\section{Stratum lusidum (lapis bening)}

Lapisan ini dibentuk oleh 2-3 lapisan sel gepeng yang tembus cahaya, dan agak eosinofilik. Tak ada inti maupun organel

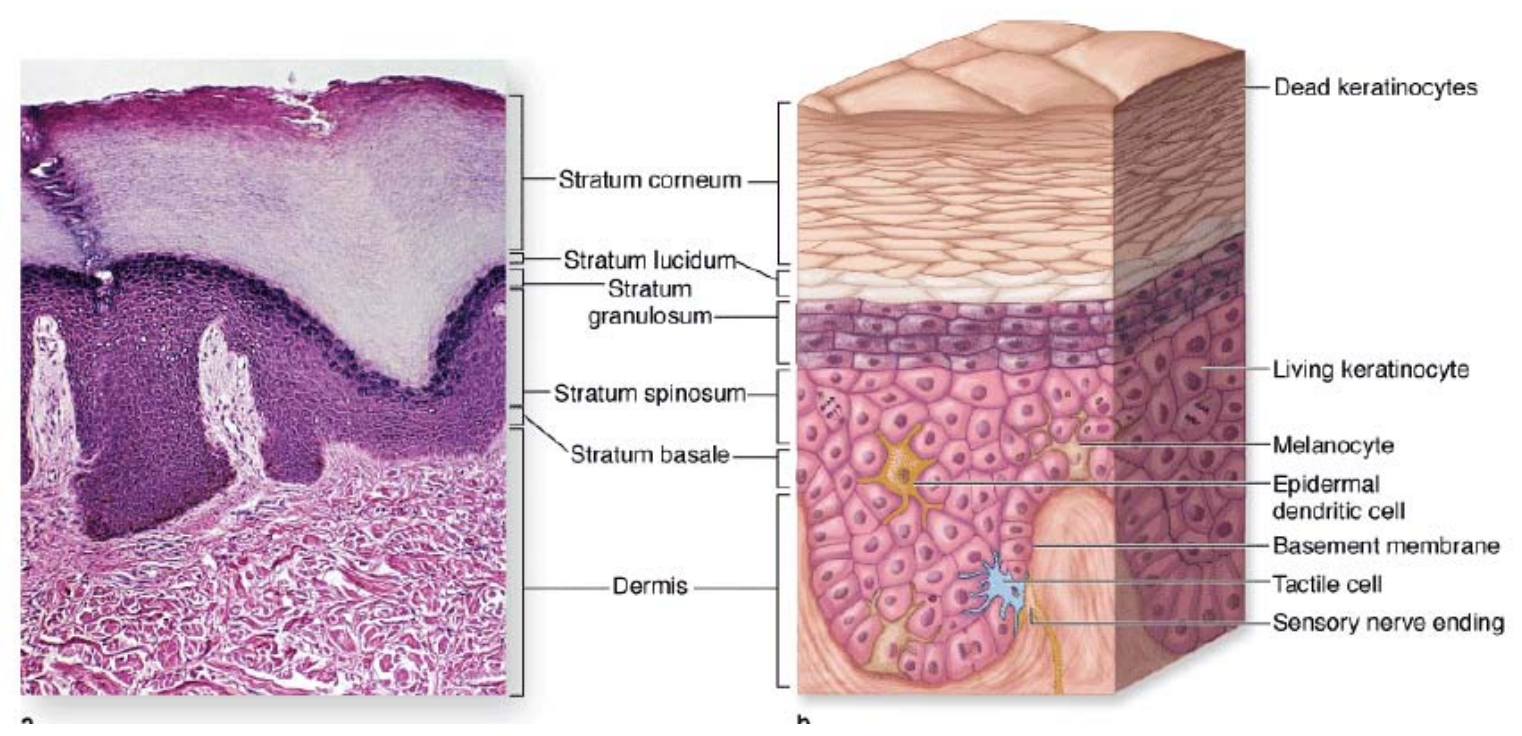

Gambar 3. Lapisan-lapisan epidermis kulit tebal. Sumber: Mescher AL, 2010. 
pada sel-sel lapisan ini. Walaupun ada sedikit desmosom, tetapi pada lapisan ini adhesi kurang sehingga pada sajian seringkali tampak garis celah yang memisahkan stratum korneum dari lapisan lain di bawahnya.

\section{Stratum korneum (lapis tanduk)}

Lapisan ini terdiri atas banyak lapisan sel-sel mati, pipih dan tidak berinti serta sitoplasmanya digantikan oleh keratin. Selsel yang paling permukaan merupa-kan sisik zat tanduk yang terdehidrasi yang selalu terkelupas.

\section{Sel-sel epidermis}

Terdapat empat jenis sel epidermis, yaitu: keratinosit, melanosit, sel Langerhans, dan sel Merkel.

\section{Keratinosit}

Keratinosit merupakan sel terbanyak (85-95\%), berasal dari ektoderm permukaan. Merupakan sel epitel yang mengalami keratinisasi, menghasilkan lapisan kedap air dan perisai pelidung tubuh. Proses keratinisasi berlangsung 2-3 minggu mulai dari proliferasi mitosis, diferensiasi, kematian sel, dan pengelupasan (deskuamasi). Pada tahap akhir diferensiasi terjadi proses penuaan sel diikuti penebalan membran sel, kehilangan inti organel lainnya. Keratinosit merupakan sel induk bagi sel epitel di atasnya dan derivat kulit lain.

\section{Melanosit}

Melanosit meliputi $7-10 \%$ sel epidermis, merupakan sel kecil dengan cabang dendritik panjang tipis dan berakhir pada keratinosit di stratum basal dan spinosum. Terletak di antara sel pada stratum basal, folikel rambut dan sedikit dalam dermis. Dengan pewarnaan rutin sulit dikenali. Dengan reagen DOPA $(3,4-$ dihidroksi-fenilalanin), melanosit akan terlihat hitam. Pembentukan melanin terjadi dalam melanosom, salah satu organel sel melanosit yang mengandung asam amino tirosin dan enzim tirosinase. Melalui serentetan reaksi, tirosin akan diubah menjadi melanin yang berfungsi sebagai tirai penahan radiasi ultraviolet yang berbahaya.

\section{Sel Langerhans}

Sel Langerhans merupakan sel dendritik yang bentuknya ireguler, ditemukan terutama di antara keratinosit dalam stratum spinosum. Tidak berwarna baik dengan HE. Sel ini berperan dalam respon imun kulit, merupakan sel pembawa-antigen yang merangsang reaksi hipersensitivitas tipe lambat pada kulit.

\section{Sel Merkel}

Jumlah sel jenis ini paling sedikit, berasal dari krista neuralis dan ditemukan pada lapisan basal kulit tebal, folikel rambut, dan membran mukosa mulut. Merupakan sel besar dengan cabang sitoplasma pendek. Serat saraf tak bermielin menembus membran basal, melebar seperti cakram dan berakhir pada bagian bawah sel Merkel. Kemungkinan badan Merkel ini merupakan mekanoreseptor atau reseptor rasa sentuh.

\section{Dermis}

Dermis terdiri atas stratum papilaris dan stratum retikularis, batas antara kedua lapisan tidak tegas, serat antaranya saling menjalin.

\section{Stratum papilaris}

Lapisan ini tersusun lebih longgar, ditandai oleh adanya papila dermis yang jumlahnya bervariasi antara $50-250 / \mathrm{mm}^{2}$. Jumlahnya terbanyak dan lebih dalam pada daerah di mana tekanan paling besar, seperti pada telapak kaki. Sebagian besar papila mengandung pembuluh-pembuluh kapiler yang memberi nutrisi pada epitel di atasnya. Papila lainnya mengandung badan akhir saraf sensoris yaitu badan Meissner. Tepat di bawah epidermis serat-serat kolagen tersusun rapat. 


\section{Stratum retikularis}

Lapisan ini lebih tebal dan dalam. Berkas-berkas kolagen kasar dan sejumlah kecil serat elastin membentuk jalinan yang padat ireguler. Pada bagian lebih dalam, jalinan lebih terbuka, rongga-rongga di antaranya terisi jaringan lemak, kelenjar keringat dan sebasea, serta folikel rambut. Serat otot polos juga ditemukan pada tempat-tempat tertentu, seperti folikel rambut, skrotum, preputium, dan puting payudara. Pada kulit wajah dan leher, serat otot skelet menyusupi jaringan ikat pada dermis. Otot-otot ini berperan untuk ekspresi wajah. Lapisan retikular menyatu dengan hipodermis/fasia superfisialis di bawahnya yaitu jaringan ikat longgar yang banyak mengandung sel lemak.

\section{Sel-sel dermis}

Jumlah sel dalam dermis relatif sedikit. Sel-sel dermis merupakan sel-sel jaringan ikat seperti fibroblas, sel lemak, sedikit makrofag dan sel mast.

\section{Hipodermis}

Sebuah lapisan subkutan di bawah retikularis dermis disebut hipodermis. Ia berupa jaringan ikat lebih longgar dengan serat kolagen halus terorientasi terutama sejajar terhadap permukaan kulit, dengan beberapa di antaranya menyatu dengan yang dari dermis. Pada daerah tertentu, seperti punggung tangan, lapis ini meungkinkan gerakan kulit di atas struktur di bawahnya. Di daerah lain, serat-serat yang masuk ke dermis lebih banyak dan kulit relatif sukar digerakkan. Sel-sel lemak lebih banyak daripada dalam dermis. Jumlahnya tergantung jenis kelamin dan keadaan gizinya. Lemak subkutan cenderung mengumpul di daerah tertentu. Tidak ada atau sedikit lemak ditemukan dalam jaringan subkutan kelopak mata atau penis, namun di abdomen, paha, dan bokong, dapat mencapai ketebalan $3 \mathrm{~cm}$ atau lebih. Lapisan lemak ini disebut pannikulus adiposus.

\section{Warna kulit}

Warna kulit ditentukan oleh tiga faktor, yaitu: pigmen melanin berwarna coklat dalam stratum basal, derajat oksigenasi darah dan keadaan pembuluh darah dalam dermis yang memberi warna merah serta pigmen empedu dan karoten dalam lemak subkutan yang memberi warna kekuningan. Perbedaan warna kulit tidak berhubungan dengan jumlah melanosit tetapi disebabkan oleh jumlah granul-granul melanin yang ditemukan dalam keratinosit.

\section{PENYEMBUHAN LUKA KULIT}

Penyembuhan luka adalah suatu proses dinamik kompleks yang menghasilkan pemulihan terhadap kontinuitas anatomik dan fungsi jaringan setelah terjadi perlukaan. Penyembuhan luka dibagi dalam tiga tahap yang saling berhubungan dan tumpang tindih dalam waktu terjadinya, yaitu: 1) peradangan; 2) pembentukan jaringan (proliferasi); dan 3) remodeling jaringan.

Salah satu tujuan utama tubuh pada proses perbaikan luka kulit ialah mengembalikan fungsi kulit sebagai sawar fungsional. Reepitelisasi luka kulit dimulai 24 jam setelah luka melalui pergerakan selsel epitel dari tepi bebas jaringan melintasi defek dan dari struktur folikel rambut yang masih tersisa pada dasar luka partial thickness.

Sel-sel epitel berubah bentuk baik secara internal dan eksternal untuk memudahkan pergerakan. Metamorfosis selular ini meliputi retraksi tonofilamen intrasel, disolusi desmosom intersel dan hemi-desmosom membran basal, serta pembentukan filamen aktin sitoplasma perifer. Sel-sel epidermis pada tepi luka cenderung kehilangan polaritas apiko-basal dan menjulurkan pseudopodia dari tepi basolateral bebas ke dalam luka.

Pola pasti dari migrasi epidermis yang mengalami regenerasi ini belum diketahui, tetapi kemungkinan berupa migrasi sel tunggal melintasi permukaan luka dengan 
mekanisme "lompat-katak" (leap-frogging) atau "jejak-traktor” (tractor tread).

\section{RAMBUT}

Batang rambut merupakan struktur keratin keras yang dihasilkan oleh bangunan epitelial berbentuk kantung yaitu folikel rambut. Pada ujung basal folikel melebar melingkari papila pili terdiri atas jaringan ikat, pembuluh darah dan saraf yang penting bagi kelangsungan hidup folikel rambut; bagian yang melebar disebut bulbus pili. Sel-sel terdalam pada bulbus, yang meliputi papila pili menghasilkan batang rambut yang akan muncul ke permukaan kulit. Sel-sel yang membungkus bulbus merupakan lanjutan sel-sel stratum basal dan spinosum epidermis kulit. Sel-sel tersebut terusmenerus mengalami mitosis dan menghasilkan berbagai selubung selular bagi rambut. Sel-sel papila memiliki sifat induktif terhadap aktivitas folikel, dan nutrien dari kapilernya adalah esensial untuk fungsi normalnya. Sel-sel epitel yang membungkus papila dapat disamakan dengan sel-sel stratum basal pada epidermis, dan mereka membentuk matriks rambut. Pada dasarnya proliferasinya berfungsi menumbuhkan rambut.

\section{Folikel rambut}

Folikel rambut dikelilingi pema-datan komponen fibrosa dermis. Di antara komponen tersebut dengan epitel folikel terdapat membran vitrea non-seluler, yang merupakan membran basal sangat tebal dari lapis luar epitel folikel, yang disebut sarung akar rambut luar. Pada bagian bulbus pili, sarung akar rambut luar ini hanya setebal satu sel sesuai stratum basal epidermis. Mendekati permukaan kulit, tebalnya beberapa lapis sel dan memiliki strata menyerupai epidermis kulit tipis.

Lapis-lapis konsentris berikut dari folikel adalah sarung akar rambut dalam, yang memiliki tiga komponen: (1) lapis Henle, selapis sel gepeng yang melekat erat pada sel-sel paling dalam dari sarung akar rambut luar, (2) lapis Huxley, terdiri atas dua atau tiga baris sel-sel gepeng, (3) kutikula sarung akar rambut dalam, terdiri atas sel-sel pipih mirip sisik tersusun mirip genteng dengan tepi bebasnya mengarah ke bawah.

Pada permulaan perkembangan semua sel pada folikel aktif bermitosis akan tetapi kemudian setelah folikel terdiferensiasi sempurna hanya sel-sel bagian bawah bulbus, yaitu sel matriks, yang tetap aktif bermitosis. Sel-sel tersebutlah yang akan mengisi berbagai bagian rambut, yaitu medula, korteks, dan kutikula.

\section{Medula rambut}

Medula rambut terletak paling tengah, biasanya terlihat lebih terang daripada bagian lain. Sel-selnya berbentuk poligobal, tersusun jarang satu sama lain. Di dalam sitoplasmanya dapat terlihat sedikit pigmen melanin. Perlu diperhatikan bahwa tidak semua rambut mempunyai medula.

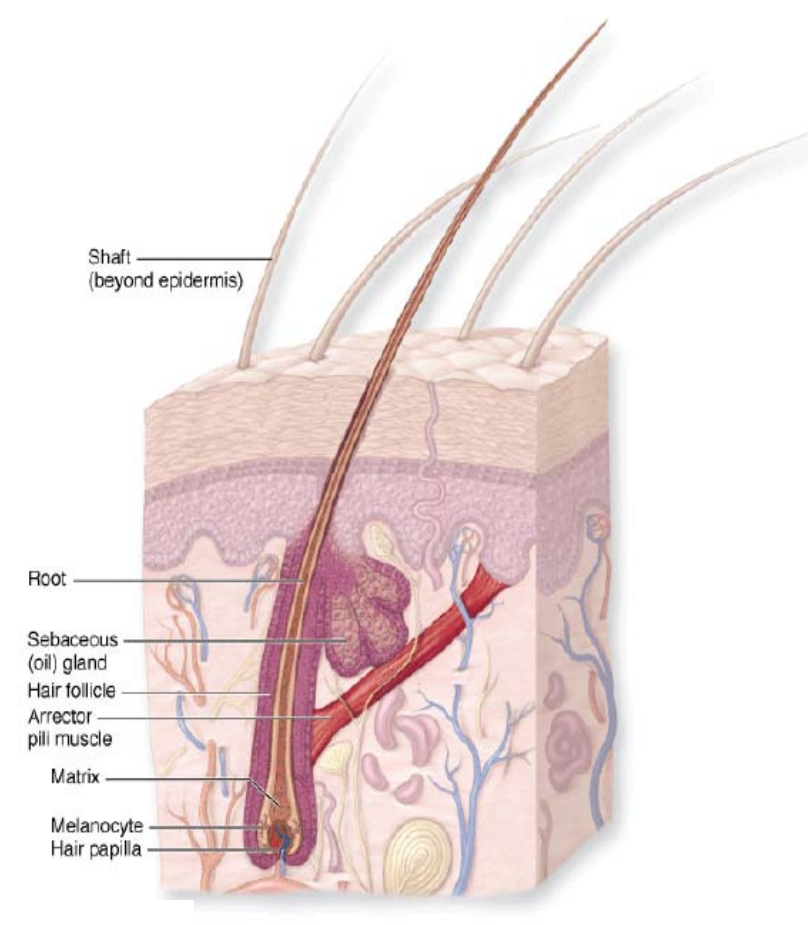

Gambar 4. Gambar skematik rambut, memperlihatkan folikel rambut, termasuk $m$. arrector pili dan kelenjar sebasea. Sumber: Mescher AL, 2010. 


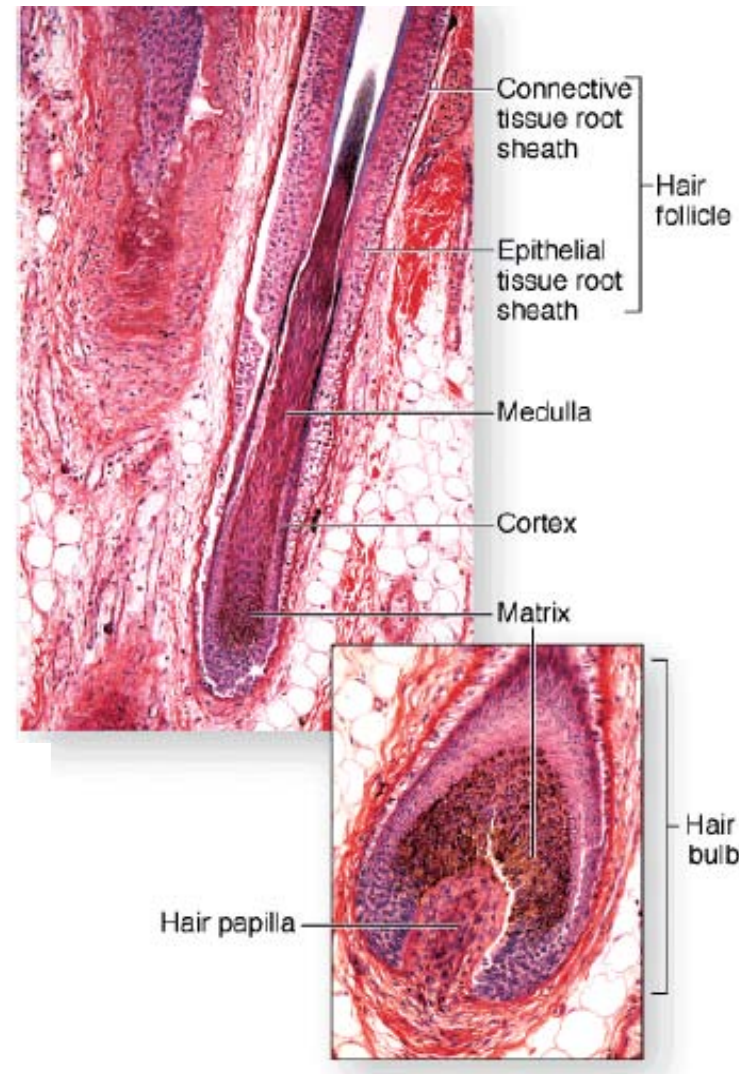

Gambar 5. Mikrograf memperlihatkan medula dan korteks pada akar rambut yang terpotong longitudinal serta sarung akar rambut. Sumber: Mescher AL, 2010.

\section{Korteks rambut}

Korteks rambut merupakan bagian terbesar rambut, mengandung beberapa lapisan konsentris yang terdiri atas sel panjang terkeratinisasi. Melanin biasanya terjepit di antara dan di dalam sel-sel ini, sehingga mewarnai rambut.

\section{Kutikula rambut}

Kutikula rambut merupakan bagian paling luar akar dan batang rambut mengandung sel-sel paling tipis, mirip sisik, dengan ujung bebas ke arah ujung distal. Sel-sel yang menyusun kutikula rambut sangat pipih, saling berselisip, dan berhimpitan dengan sel-sel kutikula sarung akar rambut dalam, sehingga sulit dibedakan satu sama lain.

\section{Pertumbuhan rambut}

Pertumbuhan dan pergantian rambut terjadi secara siklis, tidak kontinu. Periode tumbuh dan istirahatnya tergantung tempatnya pada tubuh. Rambut kepala mempunyai siklus pertumbuhan sepanjang 2-3 tahun sebelum memasuki masa istirahat selama 3-4 bulan. Pada bagian tubuh lainnya misalnya bulu mata, siklus pertumbuhan jauh lebih singkat 1-2 bulan diikuti masa istirahat 3-4 bulan. Folikel rambut biasanya berada dalam tahap yang berbeda-beda, sehingga pergantian rambut terjadi tanpa disadari.

Hormon kelamin laki-laki (androgen) dari testis dan korteks adrenal mempunyai pengaruh langsung pada pertumbuhan rambut pada wajah, aksila, dan pubis. Anak lelaki yang dikebiri sebelum pubertas tak memiliki pertumbuhan rambut yang normal seperti yang terdapat pada laki-laki, sedangkan kekerapan mencukur dan memotong rambut tidak mempunyai pengaruh yang jelas pada pertumbuhan rambut.

Apabila folikel berhenti tumbuh, rambut berhenti tumbuh, terputus dari bulbus dan akhirnya rontok. Diduga kebotakan diakibatkan oleh adanya testosteron (hormon kelamin laki-laki). Kebotakan bersifat herediter dan predisposisi genetik ini baru timbul bila terdapat hormon kelamin laki-laki; terbukti pada sida-sida (laki-laki yang dikebiri) meskipun mempunyai gen kebotakan tidak akan terjadi kebotakan.

\section{Warna rambut}

Warna rambut disebabkan oleh adanya pigmen melanin yang dibentuk oleh melanosit pada bulbus pili. Adanya berbagai macam warna asli rambut disebabkan oleh perbedaan jumlah melanin dan perbedaan jenis melanin, yaitu eumelanin (pigmen coklat-kehitaman) dan pheomelanin (pigmen merah hingga kuning). Timbulnya uban disebabkan oleh dua faktor: 1) melanosom pada bulbus kehilangan kemampuan menyintesis tirosinase, enzim penting untuk sintesis melanin; 2) batang dan bulbus rambut mengandung 
lebih banyak vakuola udara sehingga granula melanin jadi tersebar.

\section{KELENJAR SEBASEA}

Kelenjar sebasea atau kelenjar rambut merupakan kelenjar holokrin yang terdapat pada seluruh kulit yang berambut. Hampir semua kelenjar sebasea bermuara ke dalam folikel rambut kecuali yang terdapat pada puting susu, kelopak mata, glans penis, klitoris, dan labium minus. Kelenjar sebasea yang berhubungan dengan folikel rambut biasanya terdapat pada sisi yang sama dengan otot penegak rambut $(m$. arrector pili) (Gambar 6).

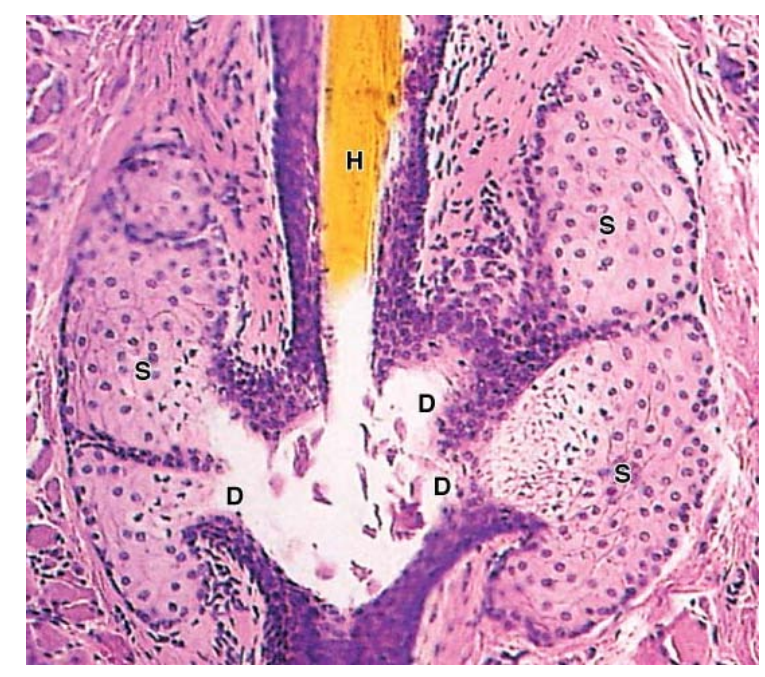

Gambar 6. Kelenjar sebasea (S) yang berhubungan dengan folikel rambut $(\mathrm{H})$. Sumber: Mescher AL, 2010.

\section{KELENJAR KERINGAT}

Kelenjar keringat ada dua jenis, yaitu kelenjar keringat merokrin dan apokrin, yang berbeda cara sekresinya. Kelenjar merokrin bergetah encer (banyak mengandung air), terdapat di seluruh permukaan tubuh kecuali daerah yang berkuku; fungsinya menggetahkan keringat yang berguna untuk ikut mengatur suhu tubuh. Kelenjar apokrin hanya terdapat pada kulit daerah tertentu, misalnya areola mamma, ketiak, sekitar dubur, kelopak mata, dan labium mayus. Kelenjar ini bergetah kental dan baru berfungsi setelah pubertas. Kelenjar bergetah lilin seperti kelenjar serumen dan kelenjar Moll juga tergolong kelenjar ini. Baik kelenjar merokrin maupun apokrin dilengkapi dengan sel mioepitel (Gambar 7).

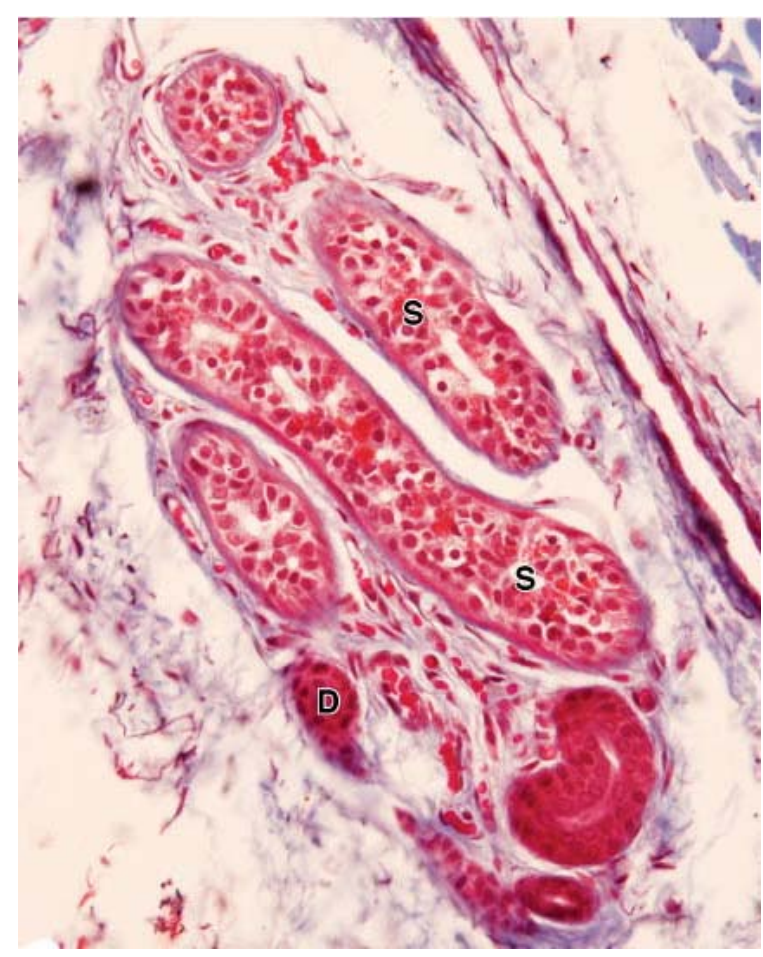

Gambar 7. Kelenjar keringat merokrin (S). Sumber: Mescher AL, 2010

\section{DAFTAR PUSTAKA}

1. Bergman RA, Afifi KA, Heidger Jr PM. Histology. Philadelphia: W.B. Saunders Company; 1996.

2. Bergman RA, Afifi KA, Heidger Jr PM. Histology. Philadelphia: W.B. Saunders Company; 1996.

3. Calvin M. Cutaneous wound repair. Wounds 1998;10:12-32.

4. Clark RAF. Cutaneous tissue repair: Basic biologic considerations. I. J Am Acad Dermatol. 1985;13:701-25.

5. Cormack DH. Ham's Histology (Ninth Edition). Philadelphia: JB Lippincott Company; 1987.

6. Fawcett DW. Bloom and Fawcett: A Textbook of Histology (Twelfth Edition). New York: Chapman \& Hall; 1994.

7. Gartner LP, Hiatt JL. Color Textbook of Histology (Third Edition). Philadelphia: 
S20 Jurnal Biomedik (JBM), Volume 5, Nomor 3, Suplemen, November 2013, hlm. S12-20

Saunders Elsevier; 2007.

8. Kessel RG. Basic Medical Histology. The biology of Cells, Tissues, and Organs. New York: Oxford University Press; 1998.

9. Kirsner RS, Eaglstein WH. The wound healing process. Dermatol Clin. 1993;11:629-40.

10. Lazarus GS, Cooper DM, Knighton DR, Margolis DJ, Pecoraro RE, Rodeheaver G, et al. Definition and guiedelines for assessment of wounds and evaluation of healing. Arch Dermatol. 1994;130:489-93.
11. McKenzie JC, Klein RM. Basic Concepts in Cell Biology and Histology. A Student's Survival Guide. New York: McGraw-Hill; 2000.

12. Mescher AL. Junqueira's Basic Histology Text \& Atlas. New York: McGraw Hill Medical; 2010.

13. Ross MH, Pawlina W. Histology a Text and Atlas (Sixth Edition). Philadelphia: Wolters Kluwer Lippincott Williams \& Wilkins; 2011.

14. Singer AJ, Clark RAF. Cutaneous wound healing. N Engl J Med. 1999;341:73846. 